\title{
Funastrain c II: A Cysteine Endopeptidase Purified from the Latex of Funastrum clausum
}

\author{
Susana R. Morcelle, ${ }^{1,3}$ Sebastián A. Trejo, ${ }^{1}$ Francesc Canals, ${ }^{2}$ Francesc X. Avilés, ${ }^{2}$ and \\ Nora S. Priolo ${ }^{1}$
}

Received January 5, 2004

\begin{abstract}
A cysteine endopeptidase, named funastrain c II, was isolated and characterized from the latex of Funastrum clausum (Asclepiadaceae). The molecular mass (mass spectrometry) of the protease was $23.636 \mathrm{kDa}$. The analysis of funastrain c II by SDS-PAGE revealed a single polypeptide chain. The enzyme showed a remarkable stability of its caseinolytic activity after incubation at temperatures as high as $70^{\circ} \mathrm{C}$. Inhibition and activation assays indicated the cysteinic nature of the funastrain c II catalytic site. The optimum $\mathrm{pH}$ of funastrain c II enzymatic activity varied according to the substrate used (9.0-10.0 for casein and 6.2-6.8 for PFLNA). Kinetic parameters were determined for $N$ - $\alpha$-CBZ-Ala $p$-nitrophenyl ester $\left(K_{\mathrm{m}}=0.0243 \mathrm{~m} M, k_{\text {cat }}=1.5 \mathrm{~s}^{-1}\right)$ and L-pyroglutamyl-L-phenylalanyl-L-leucine- $p$-nitroanilide $\left(\right.$ PFLNA; $K_{\mathrm{M}}=0.1011 \mathrm{~m} M, k_{\mathrm{cat}}=$ $\left.0.9 \mathrm{~s}^{-1}\right)$. The $\mathrm{N}$-terminal sequence of funastrain c II showed considerable similarity to other proteases isolated from latex of different Asclepiadaceae species as well as to other cysteine proteinases belonging to the papain family.
\end{abstract}

KEY WORDS: Cysteine endopeptidases; Funastrum clausum; latex; plant proteases; protein purification.

\section{INTRODUCTION}

Several plant cysteine proteases from latex have been reported. Latex of Carica papaya (Glazer and Smith, 1971; Lynn, 1979; Robinson, 1975), Ficus carica (Kramer and Whitaker, 1964; Sgarbieri et al., 1964; Sugiura and Sasaki, 1974), Ficus glabrata (Englund et al., 1968; Jones and Glazer, 1970; Kortt et al., 1974a, 1974b; Williams and Whitaker, 1969), Ficus pumila (Perelló et al., 2000), Carica candamarcensis (Gravina de Moraes et al., 1994), Calotropis procera (Dubey and Jagannadham, 2003), and of Ervatamia coronaria (Kundu et al., 2000) contains distinct cysteine proteases.

\footnotetext{
${ }^{1}$ Laboratorio de Investigación de Proteínas Vegetales (LIPROVE), Departamento de Ciencias Biológicas, Facultad de Ciencias Exactas, Universidad Nacional de La Plata, C.C. 711, B1900AVW, La Plata, Argentina.

2 Institut de Biotecnologia i de Biomedicina "Vincent Villar i Palasi," Universidad Autònoma de Barcelona, 08193 Campus UAB, Bellaterra (Cerdanyola del Vallès), Barcelona, Spain.

${ }^{3}$ To whom correspondence should be addressed. E-mail: morcelle@biol.unlp.edu.ar
}

The precise biological role of these cysteine proteases still remains uncertain, but by virtue of the broad substrate specificity they show, it is supposed that they might protect ripening fruits against plant pathogens, especially fungi and insects (Baker and Drenth, 1987).

Plant cysteine proteinases, such as papain, bromelain, and ficin, are extensively used in many industrial processes. They have been exploited commercially in

\footnotetext{
${ }^{4}$ Abbreviations: AMPSO, 3-[(1,1-dimethyl-2-hydroxyethyl)amino]2-hydroxypropanesulfonic acid; BSA, bovine serum albumin; CAPS, 3-(ciclohexylamino)-1-propanesulfonic acid; CBZ, carbobenzoxy; DMSO, dimethyl sulfoxide; DTT, dithiothreitol; E64, trans-epoxysuccinyl-L-leucylamido-(4-guanidino)butane; EDTA, ethylendiaminetetraacetic acid; IEF, isoelectric focusing; MS, mass spectrometry; MALDI TOF-MS, matrix-assisted laser desorption ionization time-of-flight mass spectrometry; MES, 2-( $N$-morpholino) ethanesulfonic acid; MOPS, 3-( $N$-morpholino $)$ propanesulfonic acid; PFLNA, L-pyroglutamyl-L-phenylalanyl-Lleucine-p-nitroanilide; SDS, sodium dodecyl sulfate; SP-Sepharose, sulfopropyl-Sepharose; TAPS, $N$-tris(hydroxymethyl)methyl-3aminopropanesulfonic acid; TCA, trichloroacetic acid; TFA, trifluoroacetic acid.
} 
food industry for meat tenderizing (to separate partially connective tissues), brewing (to solubilize grain proteins and stabilize beer), and cookie baking (to improve crispness), as well as the production of protein hydrolysates. Such preparations are currently employed to produce many foods in which enzymes can replace potentially carcinogenic or otherwise harmful chemicals. Other applications are in tanning, in leather and textile industries, to remove hair, wool, and to soften skins (Uhlig, 1998).

Pharmaceutical applications of these endopeptidases have been made for ages, since the ancient use of fig latex in digesting gastrointestinal nematodes (Hansson et al., 1986) and the introduction of bromelain as a therapeutic compound in 1957: Its actions include antitumor properties, immunity modulation, digestive assistance, enhanced wound healing, and cardiovascular and circulatory improvement, among others, even when most of its mechanisms of action are still not completely resolved (Kelly, 1996). By their action as anti-inflammatory agents and increasing the permeability of the blood-brain barrier to nutrients and therapeutic agents, plant cysteine proteases, especially bromelain and papain, have shown certain advantages for a perspective application in vivo to Alzheimer's disease patients (Krištofiková and Klaschka, 1999).

Enzymatic peptide synthesis, using proteases like catalyst, is also a growing field in which the search for endopeptidases is important. Enzymatic synthesis can usually proceed very specifically, without racemization and protection of reactant side-chains. The two main advantages of enzymatic peptide synthesis are the high specificity of the reaction and the absence of any sidechain protection requisite. Among the various enzymes studied, papain and ficin have proved to be versatile biocatalysts for the synthesis of a great variety of peptides (Barberis et al., 2000), as well as bromelain (Clapés et al., 1995). The successful application of these peptidases raises the possibility that other cysteine proteases of plant origin could be used as biocatalysts in peptide synthesis procedures.

The latex of the Asclepiadaceae plant family usually contains proteases. Studies were made on few genera such as Asclepias (Barragán et al., 1985; Brockbank and Lynn, 1979; Carpenter and Lovelace, 1943; Greenberg and Winnick, 1940; Lynn et al., 1980; Tablero et al., 1991; Winnick et al., 1940) and Calotropis (Abraham and Joshi, 1979a, 1979b; Pal and Sinha, 1980; Sengupta et al., 1984). Recently, some cysteine proteases from plants belonging to this family were purified and characterized in our laboratory from the latex of Morrenia brachystephana and Morrenia odorata (Arribére et al., 1998; Vairo Cavalli et al., 2001, 2003), Araujia hortorum (Obregón et al., 2001; Priolo et al., 2000), and Asclepias fruticosa (Trejo et al., 2001). Following this trend, the purification and characterization of funastrain c II, a protease isolated from the latex of Funastrum clausum (Asclepiadaceae), is described in this paper.

\section{MATERIALS AND METHODS}

\subsection{Chemicals}

Casein, AMPSO,${ }^{4}$ CAPS, cysteine, E-64, EDTA, MES, MOPS, L-pyroglutamil-L-phenylalanyl-L-leucine$p$-nitroanilide, $p$-nitrophenyl esters of $N$ - $\alpha$-carbobenzoxy-L-amino acids, PMSF, TAPS, DTT, Tris, and glycine were purchased from Sigma Chemical Company (St. Louis, MO, USA). Coomassie Brilliant Blue R-250, acrylamide, bisacrylamide, and low-molecular-weight markers were obtained from Bio-Rad (Hercules, CA, USA). SP-Sepharose Fast Flow and Pharmalyte 3-10 were purchased from Pharmacia (Biotech, Uppsala, Sweden) All other chemicals were obtained from commercial sources and were of the highest purity available.

\subsection{Plant Material}

Stems of Funastrum clausum (Jacq.) Schlechter [Latin synonym: Sarcostemma clausum (Jacq.) Roem. \& Schult] were obtained from plants grown in Rosario, province of Santa Fe, Argentina (Argentinean folk names: tasi, doca; English common name: white twinevine). The plant is a vine with leaves narrowly linear to broadly elliptic and white to greenish cream flowers. Voucher specimens are deposited at the UNR herbarium (Facultad de Ciencias Agrarias, Universidad Nacional de Rosario, Argentina).

\subsection{Purification of Funastrain c II}

Latex was obtained by superficial incisions of stems and collected on $0.1 M$ citric phosphate buffer (pH 6.5) containing $5 \mathrm{~m} M$ EDTA and cysteine. This suspension was first centrifuged at $16,000 \mathrm{~g}$ for $30 \mathrm{~min}$ at $4^{\circ} \mathrm{C}$ in order to discard gums and other insoluble materials, and the supernatant was ultracentrifuged at $100,000 \mathrm{~g}$ for $60 \mathrm{~min}$ at $4^{\circ} \mathrm{C}$. The resulting supernatant 
containing soluble proteins, called "crude extract," was then applied onto a Pharmacia XK 16/40 column having AK16 adaptors, packed with SP-Sepharose Fast Flow and equilibrated with $55 \mathrm{~m} M$ citric phosphate buffer ( $\mathrm{pH}$ 6.5). The chromatography was developed in an FPLC equipment (Pharmacia) by washing with the equilibrating buffer and further elution of the bound material with a sodium chloride linear gradient $(0-0.5 \mathrm{M})$ in the same buffer at a flow rate of $0.5 \mathrm{ml} / \mathrm{min}$. Cation exchange chromatography was monitored spectrophotometrically by absorption at $280 \mathrm{~nm}$. Caseinolytic activity was tested on the eluted fractions, and those showing proteolytic activity were pooled and stored at $-20^{\circ} \mathrm{C}$ for further studies.

\subsection{Physical Characterization}

\subsubsection{Protein Determination}

Measure of proteins was performed according to Bradford assay method (Bradford, 1976) using BSA as standard. The protein content of chromatography eluates was estimated by absorbance at $280 \mathrm{~nm}$ during separation.

\subsubsection{Mass Spectrometry}

Funastrain c II molecular weight and determination of its purity degree were determined by MALDI TOF-MS. Equal volumes of protein solution and MALDI matrix solution (saturated solution of sinapinic acid in $0.1 \%$ trifluoroacetic acid in water/acetonitrile 2:1) were mixed and $1 \mu \mathrm{l}$ spotted on a stainless steel target was allowed to air dry. Mass spectrum was acquired on a MALDI-TOF MS Bruker Daltonics model Ultraflex, (Billerica, MA, USA) equipped with a $\mathrm{N}_{2}$ laser $(337 \mathrm{~nm}$ ), in the positive linear mode, at an acceleration voltage of $25 \mathrm{kV}$. Bovine trypsinogen was used for internal calibration.

\subsection{Biochemical Characterization}

\subsubsection{Caseinolytic Activity Assay}

Proteolytic activity was determined by the use of casein as nonspecific substrate for crude extract and the purified fraction, according to the method described by Arribére et al. (1998). The amount of protease that produces an increment of one absorbance unit per minute in the assay conditions was considered as one caseinolytic unit $\left(\mathrm{U}_{\mathrm{cas}}\right)$ (Priolo et al. 1991).

\subsubsection{Inhibition Assays}

According to previous inhibition trials made on the crude extract, the action of E-64 was proved by incubating the enzyme with this inhibitor for $30 \mathrm{~min}$ at $45^{\circ} \mathrm{C}$. Inhibition reversion was assayed by adding cysteine to the mixture and incubating for another $30 \mathrm{~min}$ at the same temperature. The residual caseinolytic activity was measured after each incubation as indicated above.

\subsubsection{Activation Assays}

Cysteine and DTT were assayed as activators by incubating funastrain c II with each activator for $10 \mathrm{~min}$ at $45^{\circ} \mathrm{C}$. Measurement of the resulting caseinolytic activity after incubation was made to calculate the increase due to activators.

\subsubsection{Electrophoresis}

2.5.4.1. SDS-PAGE. Homogeneity of funastrain c II was assessed by SDS-PAGE with tricine cathodic buffer in $10 \%$ polyacrylamide gels (Shägger and von Jagow, 1987). Potential was kept constant at $40 \mathrm{mV}$ for the stacking gel and at $150 \mathrm{mV}$ for the resolution gel. The gels were stained with Coomassie Brilliant Blue R-250 and scanned for the approximation of funastrain c II molecular mass by using the Scion Image software. For this purpose, protein molecular weight markers (SDS-PAGE Molecular Weight Standards, Low Range, Bio-Rad) were used as standards to generate the calibration curve.

2.5.4.2. IEF and Zymogram. Funastrain c II isoelectric point $(\mathrm{pI})$ was determined by IEF, performed in a Mini IEF Cell (Model 111, Bio-Rad). The deionized sample was loaded onto a $5 \%$ polyacrylamide gel with a 3-10 $\mathrm{pH}$ gradient (Biolyte 3-10 carrier ampholytes, Bio-Rad), and the focusing of proteases present in crude extract and the purified fraction was performed according to the conditions $100 \mathrm{~V}$ for $15 \mathrm{~min}, 200 \mathrm{~V}$ for the following $15 \mathrm{~min}$, and $450 \mathrm{~V}$ for the last $60 \mathrm{~min}$. One of the resulting gels was fixed and stained with Coomassie Brilliant Blue R-250. The zymogram was obtained after contacting the unstained gel with an agarose one saturated in $1 \%$ casein solution in the presence of $12 \mathrm{mM}$ cysteine for $20 \mathrm{~min}$ at $56^{\circ} \mathrm{C}$ (Westergaard et al., 1980). Bands showing proteolytic activity were detected after incubation by dehydration and staining of the agarose gel with Coomassie Brilliant Blue R-250. 


\subsubsection{Dependence of Enzyme Activity on $\mathrm{pH}$}

Enzymatic activity dependence of funastrain c II with $\mathrm{pH}$ was proved at $45^{\circ} \mathrm{C}$ with different substrates using $10 \mathrm{~m} M$ sodium salts of the following "Good" buffers: MES, MOPS, TAPS, AMPSO and CAPS (Good and Izawa, 1972).

2.5.5.1. Using Casein as Substrate. Solutions of $1 \%$ casein with $12 \mathrm{~m} M$ cysteine were prepared at a $\mathrm{pH}$ range from 6.0 to 11.0. Trials were performed as indicated above.

2.5.5.2. Using PFLNA as Substrate. A stock solution of $1 \mathrm{~m} M$ PFLNA in DMSO was prepared, and $0.3 \mathrm{M} \mathrm{KCl}, 10^{-4} \mathrm{M}$ EDTA, and $0.003 \mathrm{M}$ DTT were added to the "Good" buffers, prepared at a $\mathrm{pH}$ range from 6.0 to 8.0. The amidasic activity was measured spectrophotometrically at $410 \mathrm{~nm}$ by the amount of $p$-nitroaniline released by the hydrolysis of the substrate after 3 min of incubation (Filippova et al., 1984).

\subsubsection{Dependence of Enzyme Activity on Temperature}

For testing proteolytic activity stability with temperature, funastrain c II was incubated for different

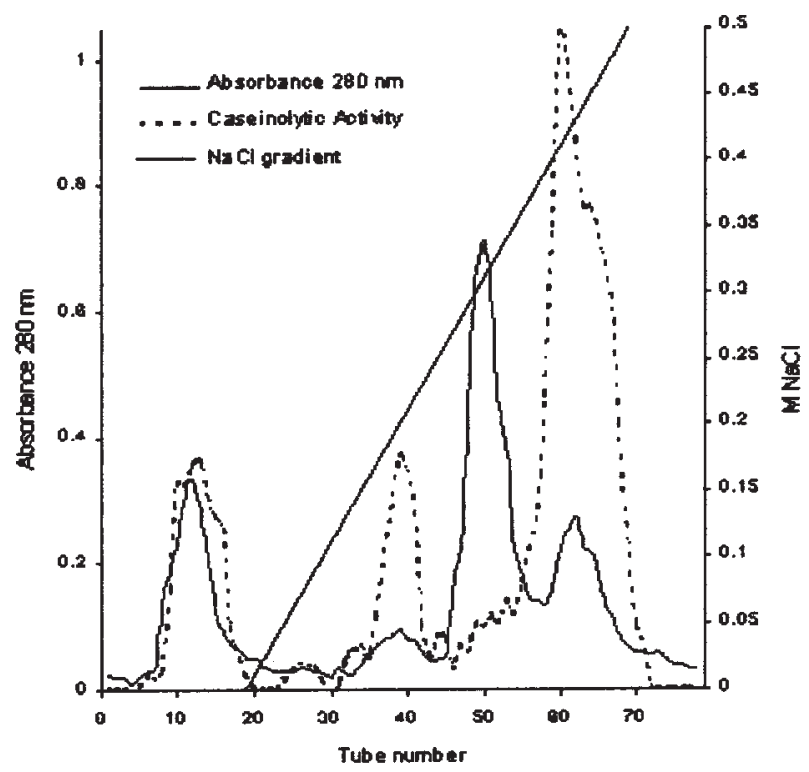

Fig. 1. Chromatographic isolation of funastrain c II. Crude extract was applied to a SP-Sepharose fast flow column equilibrated with $0.05 M$ citric phosphate buffer $\mathrm{pH}$ 6.5. The unbound material was eluted by washing with one column volume of the equilibrating buffer $(0.75 \mathrm{ml} / \mathrm{min}$ flow rate), and the bound proteins were eluted with a linear gradient of $0-05 \mathrm{M} \mathrm{NaCl}$ in the same buffer $(0.5 \mathrm{ml} / \mathrm{min}$ flow rate). Fractions of $1.3 \mathrm{ml}$ were collected. All the elution process was monitored by absorbance at $280 \mathrm{~nm}(-)$. Caseinolytic activity was measured on each fraction (- - - ). times, ranging from 2 to $120 \mathrm{~min}$, at $25,45,60$, and $70^{\circ} \mathrm{C}$. Residual caseinolytic activity was measured under standard assay condition after stopping the reaction in ice-water.

\subsubsection{Kinetic Studies}

2.5.7.1. Determination of Kinetic Parameters Using $N$-CBZ-L-Ala p-Nitrophenyl Ester as Substrate. Kinetic studies on esterolytic activity of funastrain c II were performed at $\mathrm{pH} 9.0$ and $45^{\circ} \mathrm{C}$ according to Silverstein (1974). Concentrations of $N$-CBZ-L-Ala $p$-nitrophenyl ester ranging from 0.01 to $0.125 \mathrm{~m} M$ in the mixture reaction were proved. The absorbance of the released

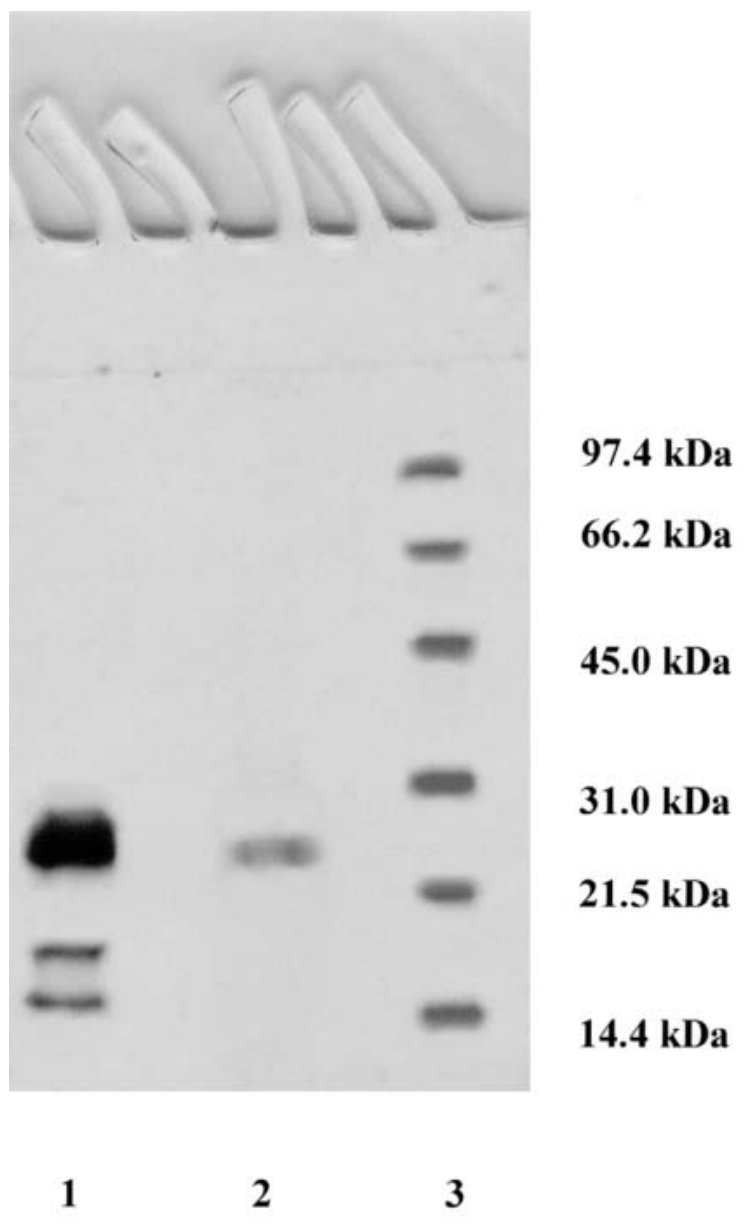

Fig. 2. SDS-PAGE of crude extract and funastrain c II on $10 \%$ polyacrylamide gel. References: lane 1, crude extract; lane 2, funastrain c II; lane 3, molecular weight standards: phosphorylase b $97.4 \mathrm{kDa}$, serum albumin $66.2 \mathrm{kDa}$, ovalbumin 45.0 $\mathrm{kDa}$, carbonic anhydrase $31.0 \mathrm{kDa}$, trypsin inhibitor $21.5 \mathrm{kDa}$, and lysozyme $14.4 \mathrm{kDa}$. Proteins were stained with Coomassie Brilliant Blue R-250. 
Table 1. Purification Table of Funastrain c II

\begin{tabular}{|c|c|c|c|c|c|c|c|c|}
\hline Sample & Volume (ml) & $\begin{array}{l}\text { Protein } \\
(\mathrm{mg} / \mathrm{ml})\end{array}$ & $\begin{array}{c}\text { Total } \\
\text { proteins }(\mathrm{mg})\end{array}$ & $\mathrm{U}_{\mathrm{cas}} / \mathrm{ml}$ & Total $\mathrm{U}_{\text {cas }}$ & $\begin{array}{c}\text { Specific } \\
\text { activity }\left(\mathrm{U}_{\mathrm{cas}} / \mathrm{mg}\right)\end{array}$ & $\begin{array}{l}\text { Purification } \\
\quad \text { (fold) }\end{array}$ & Yield (\%) \\
\hline Crude extract & 2.5 & 0.551 & 1.3375 & 0.775 & 3.514 & 1.41 & - & - \\
\hline Funastrain c II & 14 & 0.024 & 0.3416 & 0.182 & 2.548 & 7.45 & 5 & 24.8 \\
\hline
\end{tabular}

$\mathrm{U}_{\text {cas }}$, caseinolytic unit.

p-nitrophenol was followed spectrophotometrically with an Agilent 8453 E UV-visible spectroscopy system (Palo Alto, CA, USA) at $405 \mathrm{~nm}$ every $10 \mathrm{~s}$ for $2 \mathrm{~min}$. An arbitrary enzyme unit $\left(\mathrm{U}_{\mathrm{cbz}}\right)$, defined as the amount of peptidase that released $1 \mu \mathrm{mol}$ of $p$-nitrophenolate per min in the assay conditions, was created to express the esterolytic activity. A standard curve of $p$-nitrophenol was performed to determine the micromoles produced during the reaction. The resulting initial rates were plotted against substrate concentration, and kinetic

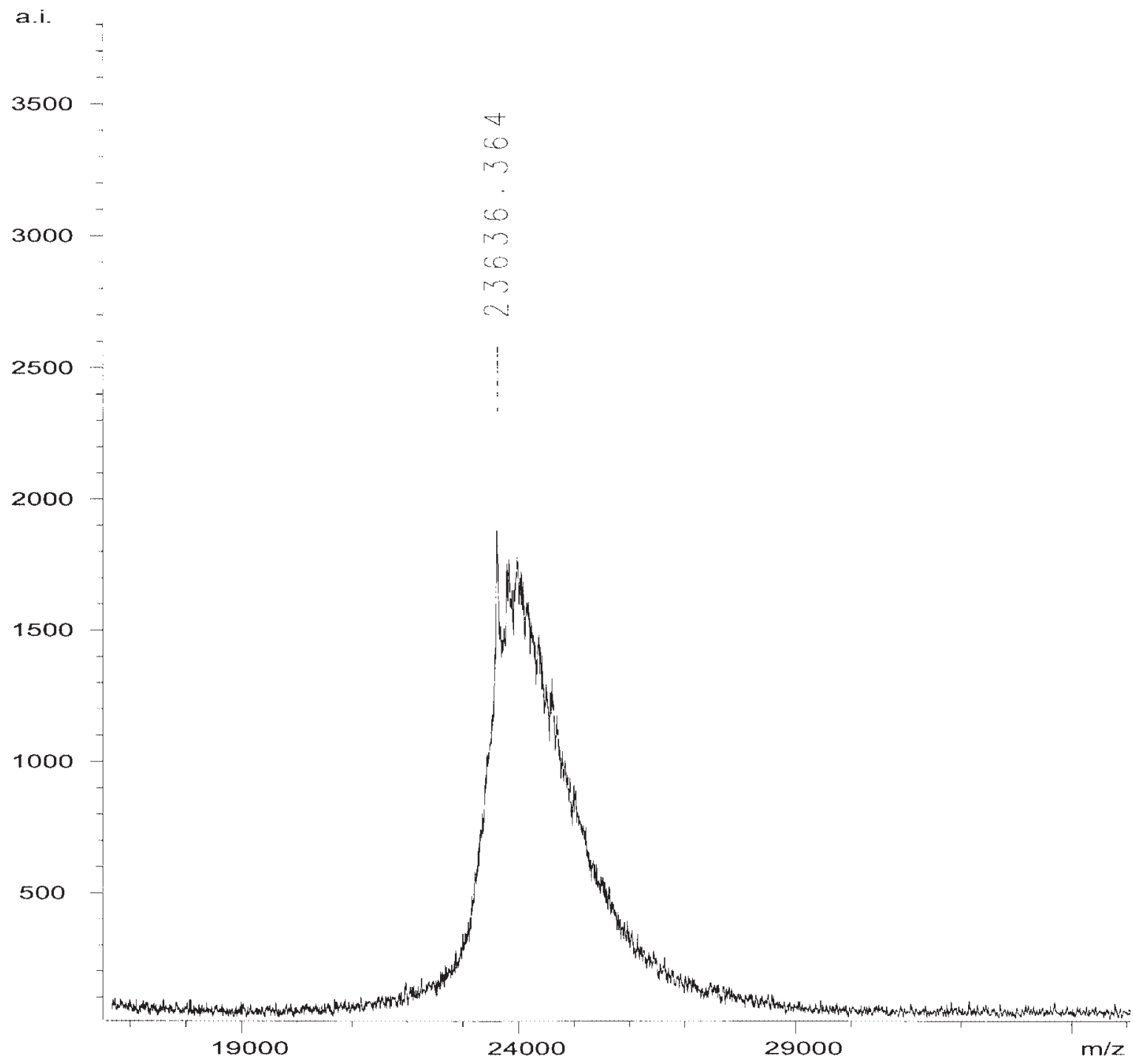

Fig. 3. Mass spectrometry of funastrain c II. Sample was prepared by mixing equal volumes of protein solution and MS matrix solution and introduced in MALDI-TOF MS equipment. Peaks at $\mathrm{m} / \mathrm{z}$ above $\mathrm{M}+\mathrm{H}^{+}$(23,634 Da) correspond probably to matrix adducts. 


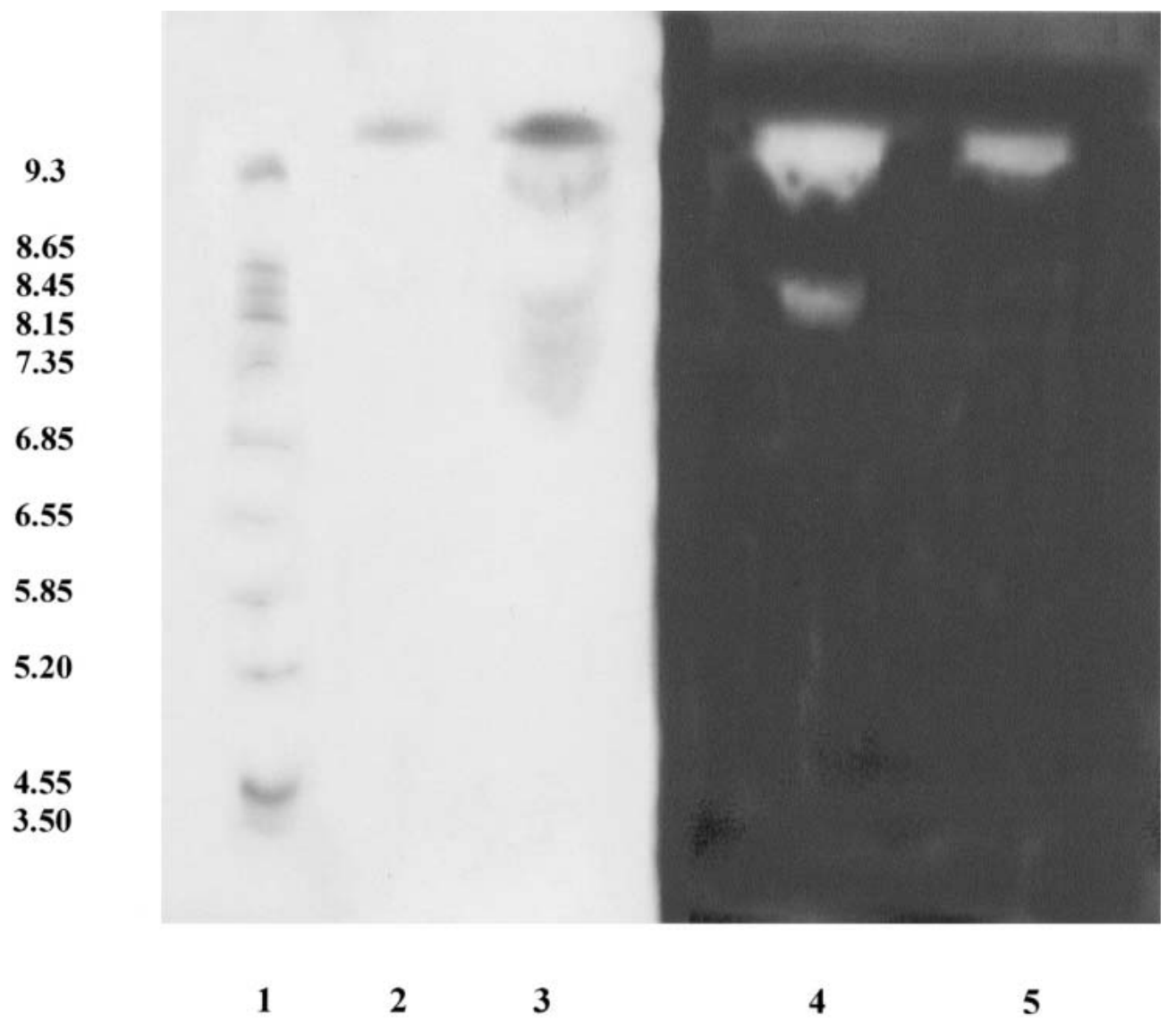

Fig. 4. IEF an zymogram of funastrain c II and crude extract. References: IEF lane 1, isoelectric point markers: amyloglucosidase from Aspergillus niger 3.6, trypsin inhibitor from soybean 4.6, $\beta$-lactoglobulin A from bovine milk 5.1, carbonic anhydrase II from bovine erythrocytes 5.9, carbonic anhydrase I from human erythrocytes 6.6, myoglobin from horse heart 6.8, 7.2, lectin from Lens culinaris 8.2, 8.6, 8.8, trypsinogen from bovine pancreas 9.3; lane 2, funastrain c II; lane 3, crude extract. Zymogram: lane 4, crude extract; lane 5, funastrain c II.

parameters $\left(K_{\mathrm{m}}\right.$ and $\left.V_{\mathrm{m}}\right)$ were calculated by nonlinear fitting using the Origin 6.0 software as well as the Lineweaver-Burk transformation.

\subsubsection{Determination of Kinetic Parameters Using} PFLNA as Substrate. Initial rates of hydrolysis were measured spectrophotometrically at $410 \mathrm{~nm}$ according to Filippova et al. (1984) at $\mathrm{pH} 6.5$ and $45^{\circ} \mathrm{C}$ for concentrations of PFLNA ranging from 0.01 to $0.5 \mathrm{~m} M$ in the reaction mixture. The amidolytic activity was expressed in an arbitrary enzyme unit ( $\left.\mathrm{U}_{\mathrm{PFLNA}}\right)$, defined as the amount of peptidase that released $1 \mu \mathrm{mol}$ of $p$-nitroaniline. $K_{\mathrm{m}}$ and $V_{\mathrm{m}}$ were calculated as indicated above.

\subsubsection{N-Terminal Sequence}

A lyophilized sample of funastrain c II was desalted by resuspension in $0.1 \%$ TFA, immobilization on a PVDF membrane on a centrifugal device (MIL-
LIPORE, Billerica, MA, USA), followed by thorough washing with water. Determination of the $\mathrm{N}$-terminal sequence was achieved by Edman's automated degradation in a Beckman LF3000 Protein Sequencer equipped with a System Gold (Beckman, Munich, Germany) PTH-aminoacid analyzer. The PSI BLAST 2.1 (Altschul et al., 1997; Schaffer, 1999) and BLAST 2 (Tatusova and Madden, 1999) network service (http://www.ncbi.nlm.nih.gov/blast; http://embnet.cifn. unam.mx/blast/wblast2.html) were used to perform the protein homology studies by comparing with those in the Swiss Prot database and the N-terminus of those purified in our laboratory.

\section{RESULTS AND DISCUSSION}

The purification of funastrain c II from the latex of Funastrum clausum (Jacq.) Schlechter was achieved 
by a two-step procedure. Centrifugation of the latex followed by further ultracentrifugation yielded the crude extract, which was further applied onto a SPSepharose column chromatograph. The elution profile is shown in Fig. 1. The unbound eluate manifested activity toward casein, as well as the two fractions eluted after the application of the linear $\mathrm{NaCl}$ gradient. The second peak showing proteolytic activity, eluted at 0.45 $M \mathrm{NaCl}$, was selected for the current study, due to its high specific activity (Table 1) and to its purity, proved by SDS-PAGE and MS (Figs. 2 and 3). The name funastrain c II for this endopeptidase was chosen according to previous suggestions (Barragán et al., 1985; Tablero et al., 1991).

Funastrain c II molecular mass obtained by SDSPAGE was $23.6 \mathrm{kDa}$, whereas by MS it was $23.636 \mathrm{kDa}$. Both techniques showed a good coincidence in their results. The molecular mass of funastrain c II was similar to those indicated for cysteine proteases from Asclepiadaceae (Vairo Cavalli et al., 2003) and lying in the range of 20-35 $\mathrm{kDa}$ reported for most of the plant cysteine proteinases (Turk et al., 1997). As SDS-PAGE was performed in reducing conditions, the appearance of a single band revealed the monomeric nature of the enzyme (Fig. 2).

Isoelectric focusing and zymogram evidenced the basic characteristic of funastrain c II ( $\mathrm{pI}$ higher than

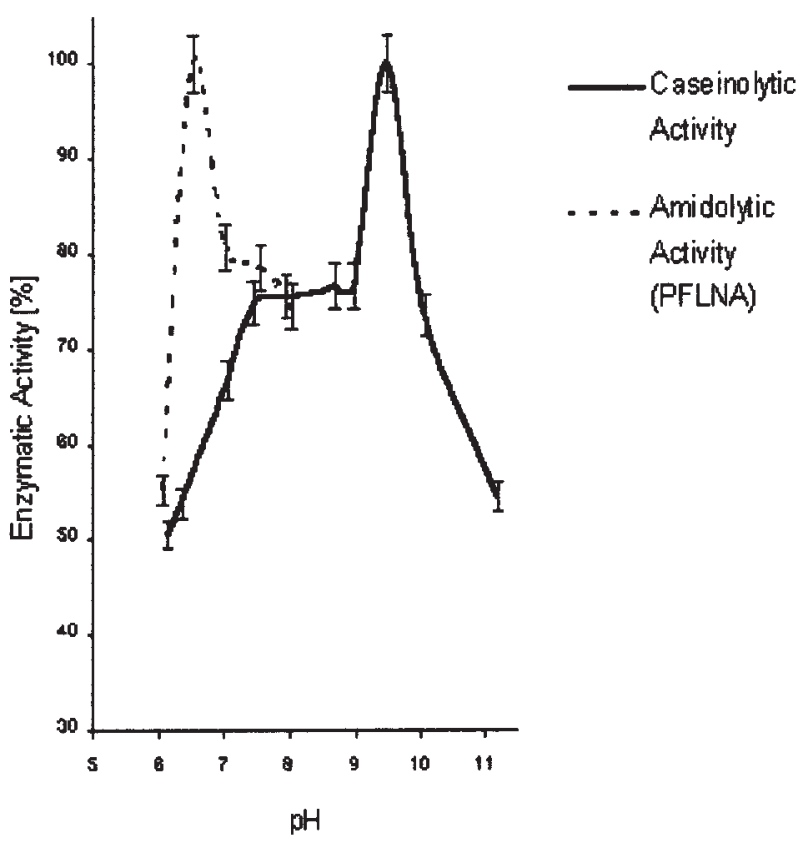

Fig. 5. Determination of optimum $\mathrm{pH}$ of funastrain c II toward casein (—) and PFLNA (- _ - ) as substrates, using the "Good" buffers. Proteolytic and amidolytic activities were measured in each case at $280 \mathrm{~nm}$ and $410 \mathrm{~nm}$, respectively.
9.3; Fig. 4), in agreement with those obtained for other peptidases from the Asclepiadaceae family latex (Trejo et al., 2001).

The cysteine residue involved in the catalytic site of the purified enzyme was manifested by the inhibition with $10 \mu M$ E-64 and by activation with reducing agents such as $12 \mathrm{~m} M$ cysteine and $5 \mathrm{~m} M$ DTT. E-64 reduced the initial caseinolytic activity of funastrain $\mathrm{c}$ II to a half after $30 \mathrm{~min}$ of incubation; the addition of $12 \mathrm{mM}$ cysteine to revert inhibition and the further incubation with the inhibitor for other $30 \mathrm{~min}$ resulted in the complete inactivation of the enzyme, demonstrating that E-64 reacted specifically with the active site of the protease (Barret et al., 1982), and inhibited it even in the presence of reducing agents used to activate cysteine proteases (Salvesen and Nagase, 2001). Because E-64 is quite a selective inhibitor for the "papain-like" cysteine endopeptidases, the obtained results could evidence that funastrain c II would be a protease related to papain (Barret et al., 1998). In opposition to the crude extract behavior (data not shown), the presence of an activator was essential to demonstrate the caseinolytic activity of funastrain c II: cysteine and DTT enhanced the catalytic activity of the enzyme up to 25 -fold.

The optimum $\mathrm{pH}$ for funastrain $\mathrm{c}$ II activity varied according to the substrate used for its determination.

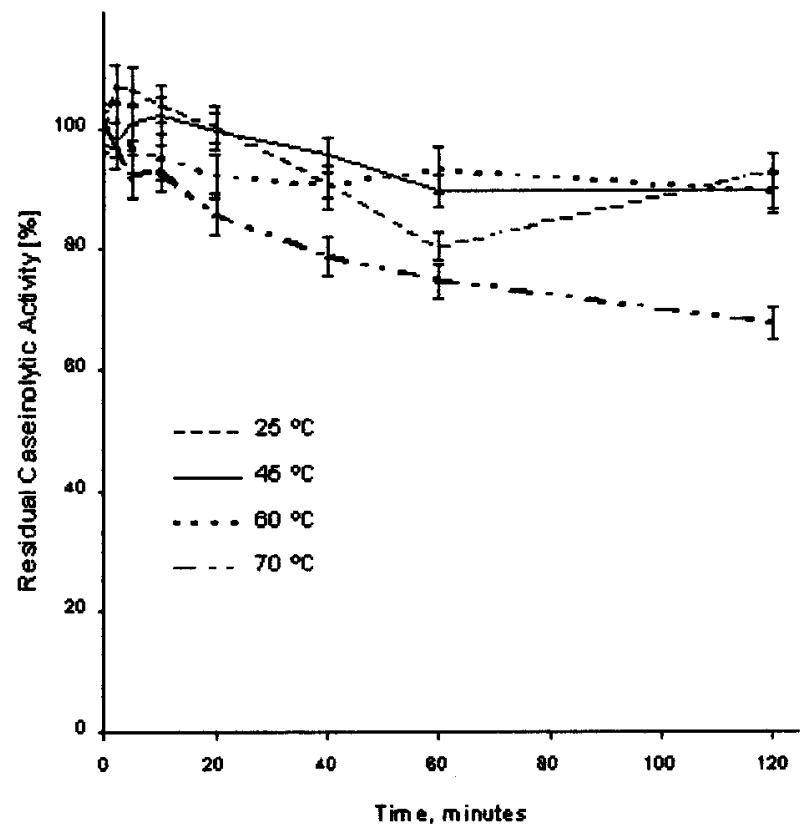

Fig. 6. Funastrain c II thermal stability. Residual caseinolytic activity of funastrain c II was measured after incubating solutions of the purified enzyme at $25,45,60$, and $70^{\circ} \mathrm{C}$. Samples were taken after $2,5,10,20,40,60$, and $120 \mathrm{~min}$ of incubation, and the activity toward casein was determined. 
Table 2. Kinetic Parameters Obtained for Funastrain c II Toward Synthetic Substrates

\begin{tabular}{|c|c|c|c|c|}
\hline Substrate & $K_{\mathrm{m}}$ & $V_{\mathrm{m}}$ & $k_{\text {cat }}$ & $k_{\mathrm{cat}} / K_{\mathrm{m}}$ \\
\hline N-CBZ-Ala $p$-nitrophenyl ester & $0.0243 \mathrm{mM}$ & $2.3 \mu \mathrm{mol} \mathrm{min}{ }^{-1}$ & $1.5 \mathrm{~s}^{-1}$ & $6.1 \times 10^{4} \mathrm{~s}^{-1} M^{-1}$ \\
\hline PFLNA & $0.1011 \mathrm{~m} M$ & $9.2 \mu \mathrm{mol} \mathrm{min}-1$ & $0.9 \mathrm{~s}^{-1}$ & $8.5 \times 10^{3} \mathrm{~s}^{-1} M^{-1}$ \\
\hline
\end{tabular}

PFLNA, L-pyroglutamyl-L-phenylalanyl-L-leucine-p-nitroanilide.

Table 3. Comparison of the Values of Kinetic Parameters Obtained for Different Asclepiadaceae Endopeptidases Toward N-CBZ-Ala $p$-Nitrophenyl Ester

\begin{tabular}{lllll}
\hline Enzyme & Funastrain c II & Morrenain b I & Morrenain b II & Morrenain o II \\
\hline$K_{\mathrm{m}}$ & $0.0243 \mathrm{~m} M$ & $0.0200 \mathrm{~m} M$ & $0.0410 \mathrm{~m} M$ & $4.3 \times 10^{-5} \mathrm{~m} M$ \\
$k_{\mathrm{cat}} / K_{\mathrm{m}}$ & $6.1 \times 10^{4} \mathrm{~s}^{-1} M^{-1}$ & $1.7 \times 10^{5} \mathrm{~s}^{-1} M^{-1}$ & $1.6 \times 10^{5} \mathrm{~s}^{-1} M^{-1}$ & $1.7 \times 10^{8} \mathrm{~s}^{-1} M^{-1}$ \\
\hline
\end{tabular}

For the natural substrate casein, the optimum $\mathrm{pH}$ for which the activity was more than $90 \%$ of the maximum was in the range of 9.0-10.0; the sharp profile shown in Fig. 5 is different to the broad $\mathrm{pH}$ range obtained for other plant thiol proteases (Dubey and Jagannadham, 2003). However, the caseinolytic activity was still retained up to more than $50 \%$ of the initial rate at $\mathrm{pH}$ values as extreme as 6.0 and 11.0. The enzymatic cleavage of the synthetic substrate PFLNA showed its maximum in the $\mathrm{pH}$ range of 6.2-6.8, in concordance with those obtained for other cysteine pro-

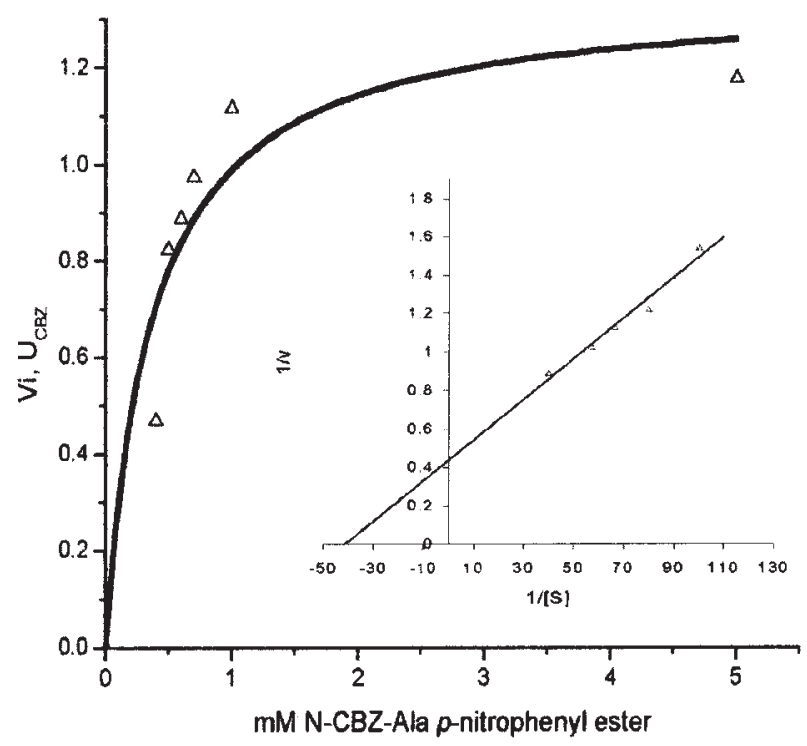

Fig. 7. Substrate (N-CBZ-L-Ala $p$-nitrophenyl ester) concentration effect on funastrain c II initial velocity. Absorbance increase at $405 \mathrm{~nm}$ versus time was measured spectrophotometrically and velocity was expressed as $\mathrm{U}_{\mathrm{CBZ}}$. Inset: Lineweaver-Burk plot. $K_{\mathrm{m}}$ and $V_{\mathrm{m}}$ were calculated according to Michaelis-Menten equation (by fitting the data with the Origin 6.0 software) and from the Lineweaver-Burk plot. teases such as papain and bromelain (Filippova et al., 1984).

As can be seen in Fig. 6, the thermostability of funastrain c II was proved to be higher than $60 \%$ up to $2 \mathrm{hr}$ of incubation at all the tested temperatures. This behavior has also been demonstrated for the crude extract (data not shown). Other cysteine proteases from latices of Asclepiadaceae, as the purified protease morrenain b II from Morrenia brachystephana, showed a similar performance (Vairo Cavalli et al., 2003). The knowledge of such parameters as optimum $\mathrm{pH}$ and

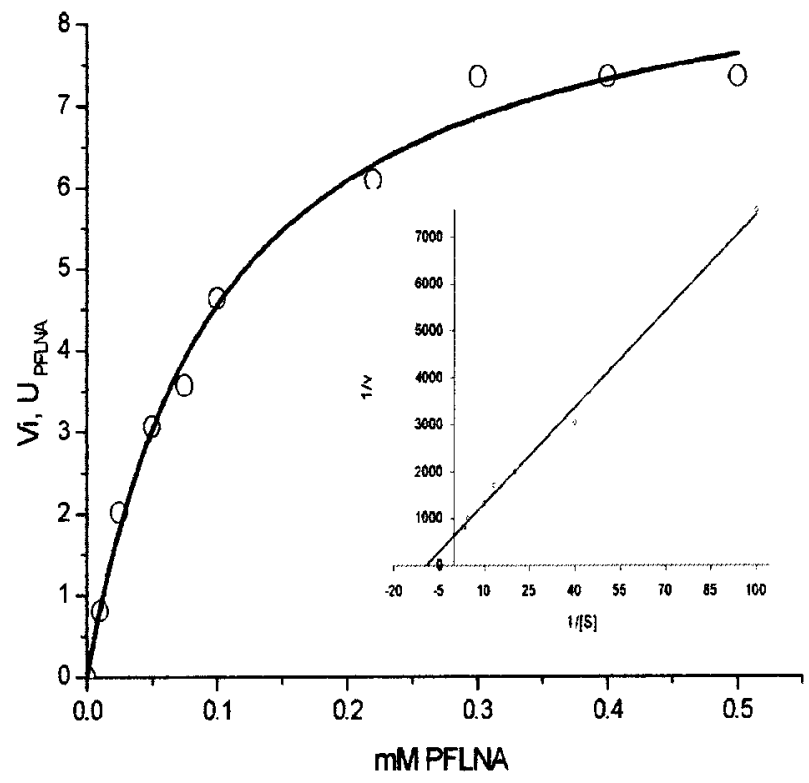

Fig. 8. Substrate (PFLNA) concentration effect on funastrain c II initial velocity. Absorbance increase at $410 \mathrm{~nm}$ versus time was measured spectrophotometrically and velocity was expressed as $U_{\text {PFLNA. }}$. Inset: Lineweaver-Burk plot. $K_{\mathrm{m}}$ and $V_{\mathrm{m}}$ were calculated according to Michaelis-Menten equation (by fitting the data with the Origin 6.0 software) and from the Lineweaver-Burk plot. 
Table 4. BLAST for Funastrain c II

\begin{tabular}{|c|c|c|c|c|}
\hline Protein and source & $\mathrm{N}$-terminal sequence & Identities \% & Positives \% & References \\
\hline \multicolumn{5}{|l|}{ Funastrum clausum } \\
\hline Funastrain c II & LPNSVDWRQKGVVSAIRNQGKCGSCXAFXAV & $31 / 31(100 \%)$ & - & Present paper \\
\hline Asclepias fruticosa & LP+SVDWR+KGVV IRNQGK & & & \\
\hline Asclepain $\mathrm{f}$ & LPDSVDWREKGVVFPIRNQGK & $17 / 21(80 \%)$ & $19 / 21(89 \%)$ & Trejo et al., 2001 \\
\hline \multirow[t]{2}{*}{ Asclepias syriaca } & LPNS+DWRQK VV I+NQG & & & \\
\hline & LPNSIDWRQKNVVFP 【KNQG & $15 / 20(75 \%)$ & $17 / 20(85 \%)$ & Lynn et al., 1980 \\
\hline Asclepain a & LPN VDWR+ GVV IRNQG+ & & & \\
\hline Asclepain b & LPNFVDWRKNGVVFPIRNQGQ & $15 / 21(71 \%)$ & $17 / 21(80 \%)$ & Lynn et al., 1980 \\
\hline \multirow{2}{*}{$\begin{array}{l}\text { Araujia hortorum } \\
\text { Araujiain h III }\end{array}$} & $\mathrm{LP}$ SVDWR $+\mathrm{K}+\mathrm{V}+\mathrm{RNQG}+\mathrm{CGSC} \mathrm{AF} \mathrm{AV}$ & & & \\
\hline & LPESVDWRKKNLVFPVRNQGQCGSCXAFSAV & $22 / 31(70 \%)$ & $26 / 31(82 \%)$ & Obregón et al., 2001 \\
\hline Oriza sativa & $\mathrm{LP} \quad \mathrm{SVDWR}+\mathrm{KG} \mathrm{V}+++\mathrm{NQG}+\mathrm{CGSC}$ AF AV & & & \\
\hline Oryzain beta chain precursor & LPESVDWREKGAVAPVKNQGQCGSCWAFSAV & $21 / 31(67 \%)$ & $26 / 31(83 \%)$ & Watanabe et al., 1991 \\
\hline Hordeum vulgare & $\begin{array}{l}\text { LP SVDWRQKG V++++QGKCGSC AF V } \\
\text { LPPSVDWRQKGAVTGVKDQGKCGSCWAFSTV }\end{array}$ & 21/31 (67\%) & 25/31 (80\%) & Koehler and Ho, 1990 \\
\hline Cysteine proteinase EP-B 2 precursor & LP SVDWRQKG V $++++\overline{Q G K C G S C}$ AF $\quad \mathrm{V}$ & & & \\
\hline Cysteine proteinase EP-B 1 precursor & LPPSVDWRQKGAVTGVKDQGKCGSCWAFSTV & $21 / 31(67 \%)$ & $25 / 31(80 \%)$ & Koehler and Ho, 1990 \\
\hline Rattus norvegicus & $\mathrm{LPN} \quad \mathrm{DWR}++\mathrm{G} \mathrm{V}++$ RNQGKCGSC $\mathrm{AF}$ AV & & & \\
\hline Cathepsin J precursor (cathepsin L-related protein) & LPNFKDWRKEGYVTPVRNQGKCGSCWAFAAV & $21 / 31(67 \%)$ & $25 / 31(80 \%)$ & Conliffe et al., 1995 \\
\hline \multirow{2}{*}{$\begin{array}{l}\text { Sus scrofa } \\
\quad \text { Cathepsin L precursor }\end{array}$} & $+\mathrm{P} \quad \mathrm{SVDWR}+\mathrm{KG} \mathrm{V}+\mathrm{A}++\mathrm{NQG}+\mathrm{CGSC} \mathrm{AF} \mathrm{A}$ & & & \\
\hline & VPKSVDWREKGYVTAVKNQGQCGSCWAFSA & $20 / 30(66 \%)$ & $26 / 30(86 \%)$ & Okamura et al., 1995 \\
\hline \multirow{2}{*}{$\begin{array}{l}\text { Morrenia brachystephana } \\
\text { Morrenain b II }\end{array}$} & $\mathrm{LP}+\mathrm{SVDWR}+\mathrm{K}+\mathrm{V} \quad+\mathrm{RNQGK} \mathrm{G}$ & & & \\
\hline & LPDSVDWRKKNLVFPVRNQGKKG & $15 / 23(65 \%)$ & $19 / 23(82 \%)$ & Vairo et al., 2001 \\
\hline \multirow{2}{*}{$\begin{array}{l}\text { Morrenia odorata } \\
\text { Morrenain o II }\end{array}$} & $\mathrm{LP}+\mathrm{SVDWR}+\mathrm{K}+\mathrm{V} \quad+\mathrm{RNQGK} \mathrm{G}$ & & & \\
\hline & LPDSVDWRKKNLVFPVRNQGKXG & $15 / 23(65 \%)$ & $19 / 23(82 \%)$ & Vairo et al., 2001 \\
\hline $\begin{array}{l}\text { Homo sapiens } \\
\text { Cathepsin L precursor }\end{array}$ & $\mathrm{P}$ SVDWR $+\mathrm{KG} \mathrm{V}+++\mathrm{NQG}+\mathrm{CGSC}$ AF $\mathrm{A}$ & & & \\
\hline Cathepsin L precursor & PRSVDWREKGYVTPVKNQGQCGSCWAFSA & $19 / 29(65 \%)$ & $24 / 29(82 \%)$ & Joseph et al., 1988 \\
\hline Carica papaya & $\begin{array}{l}\mathrm{LP}+\mathrm{VDWR}+\mathrm{KG} \mathrm{V}++\mathrm{R}+\mathrm{QG} \text { CGSC AF AV } \\
\text { LPENVDWRKKGAVTPVRHQGSCGSCWAFSAV }\end{array}$ & $20 / 31(64 \%)$ & $25 / 31(80 \%)$ & Mitchell et al. 1970 \\
\hline Papain precursor (papaya proteinase I) & $\mathrm{LP}+\mathrm{VDWR}+\mathrm{KG} \mathrm{V}++\mathrm{R}+\mathrm{QG}$ CGSC $\mathrm{AF} \mathrm{AV}$ & & & \\
\hline Caricain precursor (papaya proteinase omega) & LPENVDWRKKGAVTPVRHQGSCGSCWAFSAV & $20 / 31(64 \%)$ & $25 / 31(80 \%)$ & Dubois et al., 1988 \\
\hline Mus musculus & $+\mathrm{P}$ SVDWR $+\mathrm{KG} \mathrm{V}+++\mathrm{NQG}+\mathrm{CGSC}$ AF A & & & \\
\hline Cathepsin L precursor & IPKSVDWREKGCVTPVK NQGQCGSCWAFSA & $19 / 30(63 \%)$ & $25 / 30(83 \%)$ & Portnoy et al., 1986 \\
\hline
\end{tabular}


thermal stability are necessary to explore funastrain c II potential applications in the food and pharmaceutical industries.

Kinetic parameters $\left(K_{\mathrm{m}}, V_{\mathrm{m}}\right.$, and $\left.k_{\text {cat }}\right)$ were determined for esterolytic and amidolytic activities (Table 2). The $\mathrm{N}$-CBZ-p-nitrophenyl ester derivative of Ala was chosen for the former determinations due to the high preference showed by the crude extract (unpublished). For the latter, PFLNA was used. Because the $k_{\text {cat }} / K_{\mathrm{m}}$ ratio is considered the best kinetic quantity to express catalytic efficiency, the comparison of this parameter obtained for funastrain c II and other Asclepiadaceae proteases purified in our laboratory is shown in Table 3; the comparison of $K_{\mathrm{m}}$ values was also taken into account. For both kinetic values, funastrain c II showed a remarkable similitude with those obtained from morrenain b I and morrenain b II (Vairo Cavalli et al., 2001, 2003). The comparison of PFLNA $K_{\mathrm{m}}$ values for funastrain c II and those for papain, ficin, and bromelain (Filippova et al., 1984) revealed that the one obtained for the peptidase studied in the current work is three times higher than the others. $K_{\mathrm{m}}$ and $V_{\mathrm{m}}$ calculations were made by using the Origin 6.0 software and the Lineweaver-Burk transformation, and the results obtained in both cases were coincident (Figs. 7 and 8).

The N-terminal sequence of funastrain c II was compared with those of other proteases (Table 4). From the homology results, the undefined residues for the 26 and 29 positions were considered to be Trp and Ser, respectively, so the definitive sequence should be LPNSVDWRQKGVVSAIRNQGKCGSCWAFSAV.

A remarkable similarity ( $80 \%$ identities) between the purified protease and asclepain $\mathrm{f} \mathrm{N}$-terminus can be observed, as well as with those of asclepains a and b (75\% and $71 \%$ identities, respectively), indicating that there could be a close evolutive relation among Funastrum and Asclepias genera. The high correspondence showed by funastrain $\mathrm{c}$ II $\mathrm{N}$-terminus with others belonging to different cysteine proteases included in the clan CA, family $\mathrm{C} 1$, according to the Merops system for the classification of peptidases (Barret, 2001), indicates that the purified endopeptidase would be closely related to papain. The presence of a Cys in the 25 position could correspond to the Cys residue of the catalytic site. This evidence is reinforced by the presence of a Gln residue in the 19 position, essential for catalytic activity by helping the catalytic triad in the formation of the "oxoanion hole"; an electrophilic center that stabilizes the tetrahedral intermediate. The hydrophobic and aromatic amino acids (Trp26, Ala27, and Phe28, in our case) following the catalytic Cys consist of a usual characteristic of the proteases belonging to this family
(Barret et al., 1998). The existence of Pro2 is also a common feature in the mature proteases of family $\mathrm{C} 1$, and it is suggested that this prevents attack by aminopeptidases, due to the resistance offered by the Xaa-Pro bond to such enzymes (Barret et al., 1998).

On the whole, all the characteristics found for funastrain c II, such as the alkaline nature, its molecular weight, the optimum $\mathrm{pH}$ enzymatic activity toward different substrates, the inhibition by E-64 and activation by reducing agents, the high thermal stability, and the kinetic parameter values (especially those calculated for PFLNA), showed that the purified endopeptidase could belong to the "papain-like" family of proteases. This hypothesis would be confirmed by the analysis of its $\mathrm{N}$-terminal amino acid sequence and its comparison with those similar ones, all of them members of the mentioned family of cysteine peptidases.

\section{ACKNOWLEDGMENTS}

S. R. Morcelle and S. Trejo were awarded a fellowship by CONICET. The authors acknowledge Dr. Néstor Caffini for the revision of the manuscript. The current work was supported by grants from ANPCyT, CONICET, and UNLP.

\section{REFERENCES}

Abraham, K. I., and Joshi, P. N. (1979a). Biochim. Biophys. Acta 568: $111-119$.

Abraham, K. I., and Joshi, P. N. (1979b). Biochim. Biophys. Acta 568: $120-126$.

Altschul, S. F., Madden, T. L., Schäffer, A. A., Zhang, J., Zhang, Z., Miller, W., et al. (1997). Nucleic Acids Res. 25: 3389-3402. http://www.ncbi.nlm.nih.gov/blast.

Arribére, M. C., Cortadi, A. A., Gattuso, M. A., Bettiol, M. P., Priolo, N. S., and Caffini, N. O. (1998). Phytochem. Anal. 9: 267-273.

Baker, E. N., and Drenth, J. (1987). In: Jurnak, F., and McPherson, A. R. (eds.), Biological Macromolecules and Assemblies, John Wiley \& Sons, New York, pp. 313-368.

Barberis, S., Quiroga, E., Arribére, M. C., and Priolo, N. S. (2000). J. Mol. Catal. B Enzym. 17: 39-47.

Barragán, B. E., Cruz, M. T., del Castillo, L. M., and CastañedaAgulló, M. (1985). Rev. Latinoamer. Quím. 16: 117-119.

Barret, A. J. (1998). In: Barret, A. J., Rawlings, N. D., and Wocasner, J. F. (eds.), Handbook of Proteolytic Enzymes, Academic Press, London, pp. 546-555.

Barret, A. (2001). In: Beynon, R., and Bond, J. S. (eds.), Proteolytic Enzymes, Second Edition, Oxford University Press, Oxford, pp. $12-17$.

Barret, A. J., Kembhavi, A., Brown, M., Kirschke, H., Knight, C. G., Tamai, M., et al. (1982). Biochem. J. 201: 189-198.

Bradford, M. M. (1976). Anal. Biochem. 72: 248-254.

Brockbank, W. J., and Lynn, K. R. (1979). Biochim. Biophys. Acta. 578: $113-122$.

Carpenter, D. C., and Lovelace, F. E. (1943). J. Am. Chem. Soc. 65: 2364-2365. 
Clapés, P., Torres, J. L., and Aldercreutz, P. (1995). Bioorg. Med. Chem. 3: 245-255.

Conliffe, P. R., Ogilvie, S., Simmen, R. C., Michel, F. J., Saunders, P., and Shiverick, K. T. (1995). Mol. Reprod. Dev. 40: 146-156.

Dubey, K. V., and Jagannadham, M. V. (2003). Phytochemistry 62: $1057-1071$.

Dubois, T., Kleinschmidt, T., Schenk, A. G., Looze, Y., and Braunitzer, G. (1988). Biol. Chem. Hoppe-Seyler 369: 741-754.

Englund, P. T., King, T. P., Craig, L. C., and Walti, A. (1968). Biochemistry 7: 163-175.

Filippova, I. Yu., Lysogorskaya, E. N., Oksenoit, E. S., Rudenskaya, G. N., and Stepanov, V. M. (1984). Anal. Biochem. 143: 293-297.

Glaizer, A. N., and Smith, E. L. (1971). In: Boyer, P. D. (ed.), The Enzymes, Academic Press, New York, Vol. III, pp. 501.

Good, N. E., and Izawa, S. (1972). Meth. Enzymol. 24: 53-68.

Gravina de Moraes, M., Termignoni, C, and Salas, C. (1994). Plant Science 102: 11-18.

Greenberg, D. M., and Winnick, T. (1940). J. Biol. Chem. 135: 775-780.

Hansson, A., Veliz, G., Naquira, C, Amren, M, Arroyo, M., and Arevalo, G. (1986). J. Ethnopharmacology 17: 105-138.

Jones, I. K., and Glazer, A. N. (1970). J. Biol. Chem. 245: 2765-2772.

Joseph, L. J., Chang, L. C., Stamenkovich, D., and Sukhatme, V. P. (1988). J. Clin. Invest. 81: 1621-1629.

Kelly, G. (1996). Altern. Med. Rev. 1: 243-257.

Koehler, S. M., and Ho, T. H. (1990). Plant Cell. 2: 769-783.

Kortt, A. A., Hamilton, S., Weeb, E. C., and Zerner; B. (1974a). Biochemistry 13: 2023-2028.

Kortt, A. A., Hinds, J. A., and Zerner, B. (1974b). Biochemistry 13: 2029-2037.

Kramer, D. E., and Whitaker, J. R. (1964). J. Biol. 239: 2178-2183.

Krištofiková, Z., and Klaschka, J. (1999). Physiol. Res. 48(Suppl. 1): S87.

Kundu, S., Sundd, M., and Medicherla, V. J. (2000). J. Agric. Food Chem. 48: 171-179.

Lynn, K. R., and Yaguchi, M. (1979). Biochim. Biophys. Acta 581: 363-4.

Lynn, K. R., Brockbank, W. J., and Clevette, N. A. (1980). Biochim. Biophys. Acta 612: 119-125.

Mitchel, R. E., Chaiken, I. M., and Smith, E. L. (1970). J. Biol. Chem. 245: 3485-3492.

Obregón, W. D., Arribére, M. C., Morcelle del Valle, S., Liggieri, C., Caffini, N. O., and Priolo, N. S. (2001). J. Protein Chem. 20: $17-25$.
Okamura, N., Tamba, M., Uchiyama, Y., Sugita, Y., Dacheux, F., Syntin, P., et al. (1995). Biochim. Biophys. Acta 1245: 221-226.

Pal, G., and Sinha, N. K. (1980). Biochem. Biophys. 202: 321-329.

Perelló, M., Arribére, M. C., Caffini, N. O., and Priolo, N. S. (2000). Acta Farm. Bonaerense 19: 257-262.

Portnoy, D. A., Erickson, A. H., Kochan, J., Ravetch, J. V., and Unkeless, J. C. (1986). J. Biol. Chem. 261: 14697-14703.

Priolo, N. S., López, L. M. I., Arribére, M. C., Natalucci, C. L., and Caffini, N. O. (1991). Acta Alimentaria 20: 189-196.

Priolo, N., Morcelle del Valle, S., Arribére, M. C., López, L. M. I., and Caffini, N. (2000). J. Protein Chem. 19: 39-49.

Robinson, G. W. (1975). Biochemistry 14: 3695-700.

Salvesen, G. S., and Nagase, H. (2001). In: Beynon, R. and Bond, J. S. (eds.), Proteolytic Enzymes, Second Edition, Oxford University Press, Oxford, pp. 116-119.

Schaffer, A. A., Wolf, Y. I., Ponting, C. P., Koonin, E. V., Aravind, L., and Altschult, S. F. (1999). Bioinformatics 15: 1000-1011.

Sengupta, A., Bhattacharya, D., Pal, G., and Sinha, N. K. (1984). Biochem. Biophys. 232: 17-25.

Sgarbieri, V. C., Gupte, S. M., Kramer, D. E., and Whitaker, J. R. (1964). Biol. Chem. 239: 2170-2177.

Shägger, H., and von Jagow, G. (1987). Anal. Biochem. 166: 368-379.

Silverstein, R. M. (1974). Anal. Biochem. 62: 478-484.

Sugiura, M., and Sasaki, M. (1974). Biochem. Biophys. Acta 350: $38-47$.

Tablero, M., Arreguín, R., Arreguín, B., Soriano, M., Sánchez, R. I., Rodríguez Romero, A., et al. (1991). Plant Sci. 74: 7-15.

Tatusova, T. A., and Madden, T. L. (1999). FEMS Microbiol. Lett. 174: 247-250; http://embnet.cifn.unam.mx/blast/wblast2.html.

Trejo, S. A., López, L. M. I, Cimino, C. V., Caffini, N. O., and Natalucci, C. L. (2001). J. Protein Chem. 20: 445-453.

Turk, B., Turk, V., and Turk, D. (1997). Biol. Chem. 378: 141-150.

Uhlig, H. (1998). In: Industrial Enzymes and Their Applications. John Wiley \& Sons, New York, pp.146-147.

Vairo Cavalli, S. E., Cortadi, A., Arribére, M. C., Conforti, P., Caffini, N. O., and Priolo, N. S. (2001). Biol. Chem. HoppeSeyler 382: 879-883.

Vairo Cavalli, S., Arribére, M. C., Cortadi, A., Caffini, N. O., and Priolo, N. S. (2003). J. Protein Chem. 22: 15-22.

Watanabe, H., Abe, K., Emori, Y., Hosoyama, H., and Arai, S. (1991). J. Biol. Chem. 266: 16897-16902.

Westergaard, J. L., Hackbarth, C., Treuhaft, M. W., and Roberts, R. C. (1980). J. Immunol. Methods 34: 167-175.

Williams, D. C., and Whitaker, J. R. (1969). Plant Physiol. 44: 1574-83.

Winnick, T., Davis, A. R., and Greenberg, D. M. (1940). J. Gen. Physiol. 23: 275-288. 